Meta

Journal des traducteurs

Translators' Journal

\title{
Ogun Abibiman: A Creative Translation of Yoruba Verse
}

\section{Mabel Osakwe}

Volume 43, numéro 3, septembre 1998

URI : https://id.erudit.org/iderudit/003768ar

DOI : https://doi.org/10.7202/003768ar

Aller au sommaire du numéro

Éditeur(s)

Les Presses de l'Université de Montréal

ISSN

0026-0452 (imprimé)

1492-1421 (numérique)

Découvrir la revue

Citer cet article

Osakwe, M. (1998). Ogun Abibiman: A Creative Translation of Yoruba Verse.

Meta, 43(3), 467-471. https://doi.org/10.7202/003768ar

\section{Résumé de l'article}

L'auteur discute des différentes stratégies adoptées par Wole Soyinka pour traduire sa poésie du yoruba vers l'anglais en examinant chacune des quatre catégories stylistiques du yoruba. 


\section{BLOC-NOTES}

\section{OGUN ABIBIMAN: A CREATIVE TRANSLATION OF YORUBA VERSE}

\section{Résumé}

L'auteur discute des différentes stratégies adoptées par Wole Soyinka pour traduire sa poésie du yoruba vers l'anglais en examinant chacune des quatre catégories stylistiques du yoruba.

\section{Abstract}

This paper discusses the strategies adopted by Wole Soyinka in translating his poetry from Yoruba to English. Each of the four Yoruba stylistic categories is examined.

The process of substituting a text in one language for a text in another is often confronted with the problem of finding Target Language (TL) translation equivalents for Source Language (SL) (Catford 1964). A writer of African Literature in English in using his second language $\left(\mathrm{EL}_{2}\right)$ faces this problem as he attempts to explicate one culture in the language of a non-cognate culture. As a locus of contact of two languages, he is naturally faced with the problems and prospects of translation since he has two grammars available to him. His level of bilingualism shows in the manner he manipulates these grammars (Lado 1957; Weinreich 1953; Banjo 1976; Osundare 1979).

The manner of tackling the bilingual and bicultural problems at the conceptual and composition stage is one of such instances that reveals the level of bilingualism. Hence one bilingual may have to create the idea in his $\mathrm{L}_{1}$ before translating while another who spends most of his time using the $\mathrm{L}_{2}$ and listening to it being spoken and therefore stands the chance of thinking in his $L_{2}$ may not experience so wide a gap between thought and linguistic action.

Wole Soyinka's bilingual competence falls within the latter range. But even with a competent bilingual, it is still not easy to discover textual equivalents the reason being that bilingual competence is just one of the factors that constrain a writer's choice of language; others being message and audience/addressee. African writers of $\mathrm{L}_{2}$ expression have therefore, evolved some strategies to solve the problem of cultural and linguistic translatability.

These strategies include literal and creative translations. The former refers to a verbatim translation of $\mathrm{L}_{1}$ to $\mathrm{L}_{2}$ while the latter is a more intricate intermesh of the conceptual, perceptual and semantic levels.
Where there is a serious problem of arriving at an adequate Translation Equivalent (TE), the untranslatable item is transferred and its intelligibility ensured as the writer cushions the new item into a new surrounding; a method referred to as cushioning (Young 1970; Osundare 1979).

The strategies adopted by Wole Soyinka in translating his message in his third volume of poetry (Ogun Abibiman) is the focus of this paper. His attempt at substituting his $\mathrm{L}_{1}$ text with an $\mathrm{L}_{2}$ text is of special interest in this volume where the poet though seeking (if possible) to speak to Africans in an African language, is constrained by the linguistically heterogenous nature of their societies to adopt a borrowed tongue. Four Yoruba stylistic categories: Owe, Ofo, Alo Apama and Oriki (Olatunji 1971) are identified and their translation method examined to reveal the poet's manner of reconciling his linguistic worlds.

This short volume published in 1976 is an extolment of the Black World - a panegyric acclaiming the war against Apartheid. His adopted $\mathrm{L}_{2}$ medium here exhibits obvious signals of an expressive compromise in a number of ways. The title is one of such compromises; being a blend of Yoruba (Ogun $=\operatorname{god}$ of war and creativity) and Akan (Abibiman = the land of the black peoples) to arrive at the acronym meaning "Ogun of the black peoples."

The rather copious use of untranslated Yoruba usages is also another. But more important is the manner in which Yoruba stylistics is translated to give this poem of English expression a striking flavour of the African language.

According to Olatunji (1971) the eight stylistic features shared by all Yoruba poetic types are: repetition, lexical matching, parallelism, tonal counterpart, word play, rhythm, non causal language, and figurative language. His detailed description of these features reveals a high percentage of overlap between EL, stylistic strategies and those of $\mathrm{YL}_{1}$. English poetry employs all Yoruba stylistic features listed above except the tonal effect; a very high percentage $(87.5 \%)$ similarity which suggests that at the level of stylistic translation the Yoruba bilingual poet does not have much translation problems.

But this is not really the case. Apart from the tonal features which are untranslatable, the manner of textual organisation of the other features sets $\mathrm{YL}_{1}$ poetry distinctly apart from $\mathrm{EL}_{1}$ poetry. How then does this poet effectively translate these forms?

Meta, XLIII, 3, 1998 


\section{ORIKI THIS IS YORUBA PANEGYERIC POETRY}

In the poet's native tradition it is the most utilitarian in function since it is used as part of daily life; quite often beside the neonate's cradle in form of praise names and to refer to the mystical world of their pantheon to extol heroic deeds of divinities. There are five main discourse features: fluidity of structure and content, high incidence of nominalisation, predonderance of phrases omo, baba, and oko meaning descendant of, father of or husband of, oblique references needing extensive historical and or mythological exegesis for comprehension, the commonest being prefix + clause and prefix + nominal and multiplicity of references to the subject of oriki.

The following are some examples of Soyinka's Oriki of $\mathrm{EL}_{2}$ expression (the integrated structural analysis is mine):

1. Ar/Sc ((c) Lost (A) in dreams of Noliwe) (s) 1, Shaka

QNwg ((H) Dread Qr/Sc ((sub that $(\mathrm{P})$ takes $(\mathrm{C})$

bull elephant (A) by strom

QNwg ((H) Voice Qr/Sc ((sub that $(\mathrm{P})$ breaks $(\mathrm{A})$

upon their mad stampede

(Cord) And (P) brings (C) them (C) low (A) on

trembling knee.

QNwg ((H) Trumpet Qr/Sc ((C) raised (A) In

homage,)) (S) 1, Shaka

$\mathrm{Qr} / \mathrm{Sc}((\mathrm{P})$ Sunk (A) in gossamer memories of she

Qr/Sc ((S) whose naming $(\mathrm{P})$ was $(\mathrm{C})$ Breeze-thatcools-Bayette's blood

(P) Felt $(\mathrm{C})$ the rain of sand $(\mathrm{A})(\mathrm{PwG})$ (as nerve ends)

(PwG) (on my hairless head) and (P) knew (C) (this

tread -

$\mathrm{Q} / \mathrm{pwG}$ (of (cve) wooded rock hills, QNwG

(shredded mist of Idanre

NwG (The heart of furnaces, and pulsing ore

QNwG (Clang of anvils, (Q)/NwG (fearsome rites of passage

QNwG (Harvest in and out of season, Q/NwG

(hermit of feet

Qr/Sc ((P) Performed (A) in earth and dung of all

Abibiman

QNwG (Shape of dread Qr/Sc (S) whose silence (P)

frames $(\mathrm{C})$ the awsome

(NwG) Act of Origin-(S) 1 (P) feel, and know (C)

your tread (A) As mine $))))$ )) )) )) ))

2. $\mathrm{Ar} / \mathrm{Sc}((\mathrm{A})$ In time of race, $(\mathrm{S})$ no beauty $(\mathrm{P})$ Slights (C) the duiker's

((A) In time of strength, (S) the elephant (P) stands (C) alone

((A) In time of hunt, $(\mathrm{S})$ the lion's grace $(\mathrm{P})$ is $(\mathrm{C})$ holy

((A) In time of flight, (S) the egret (P) mocks (C) the envious

(A) In time of strife, (S) none (P) vies (A) with

Him.

(Q) Of seven paths (C) Ogun Qr/Sc ((S) who (P) to right (C) a wrong
(P) Emptied (C) reservoir of blood in heaven $(\mathrm{Sub})$ Yet $(\mathrm{P})$ raged $(\mathrm{A})$ with thirst)) )) ))) - (S) $1(\mathrm{P})$ read

(C) His savage beauty (A) on black brows... (pages 7 and 22).

The structural analysis of the examples shows how heavily clustered their NP structures are; comprising phrases and clauses with nominal functions and multiple embeding. These complex structures arise because of the use of multiple references to the same subject of Oriki: Shaka is referred to as dread..., voice..., trumpet..., etc. in 1 while Ogun is referred to as duiker, elephant, lion, egret, him of seven paths in 2. Oblique references employed include Bayette's blood, and mist of Idanre in 1 and emptied reservoirs of blood in heaven, and raged with thirst in 2 . These Oriki usages are adulatory and inspirational in function. The sentential naming structure (see seventh line of example 1) is also a translation of Oriki stylistic features.

The effect of the chanted Oriki in 2 is sustained by the repetition of the inverted qualifying adverbial string In time of; a rhetorical style that is typically Yoruba especially in its African fable characters which add proverbial and evocative functions to the chant; enabling the poet to build up to the climax of Ogun's amoral act.

\section{OWE}

Aphorisms, idioms, proverbs and related usages comprise this poetic form. Four stylistic features typify Owe. First is the function of the prescriptive function of the sentences which serve as social charters to recommend and condemn practices. These statements can be negative, positive or conditional. Negative maxims are either of the ki-type (which express who does not), or the ko-type (what does not take place). Second is the sentence form: the use of parallel sentences is higher in proverbs than in any other poetic type. For example:

Idin ni iku igbin

Ori ni iku awun

The bottom is the death of the snail

The head is the death of the tortoise (cf. Olatunji $1970: 254$ )

The parallel $k i$-type (of simple sentence) and $b i$ type (of complex) is used more often. $K i$ is the negative habitual tense marker and $b i$ the conditional as in this example:

\section{Bi a logun eru}

Bi a logun iwafa

Omo eni lere eni

If one has twenty slaves

If one has thirty pawns

One's children are one's gains (Olatunji 1970: 255) 
Third, lexical repetition and contrast; lexical items some of which contrast in meaning are repeated in the same or different clauses; for example:

Oni baje ko won

Awon gogo bi atunnise

TE Those that spoil are not scarce

What is scarce is those that improve (Olatunji 1970: 257)

Fourth is the terseness of the text, arising from condensation of pithy ideas with all their nuances within a small space. The following usages by the poet ate Owe translations. We shall group our selected examples into three, based on what characteristic features of Owe are utilized. The first group is based on the use of the first and fourth features:

3. The termites that would eat the kingdom

First built their nest

In the loin-cloth of the king (p. 13)

4. The gods that show remorse ley claims to man's

Forgiveness $-\mathrm{a}$ founder-king shall dare no less ( $\mathrm{p}$. 14)

5. Bid all beware the scorpion in the thatch -

His cunning lacks all shame

Make note of the dealer in death

A stink of the hyena, gorged in carrion. (p. 15)

6. I know - who more than I? the trade

of courtiers thrives on fawning... (p. 16)

All four examples exploit the positive maxim of Owe to either warn (5), condemn (3), satirize (6) or condemn (4). All four are terse and meaning laden. Example 4 and 5 are proverbs and 6 is an idiom. Example 3 is an aphorism in which the poet suggests the first step towards the cleansing of the African continent. The bitter truth expressed by this Owe is that the problems of apartheid which is now eating up the continent (kingdom) can actually be traced back to an earlier aparthy bred and nurtured by the traditional Africal rulers (Shaka being the chief example).

The use of Yoruba traditional symbols: termite, loin-cloth, scorpion in the thatch, hyena, dealer in death (which evokes Ogun) as well as the anthropomorphised gods of 4 and archaism employed in 5, all together combine to produce the $\mathrm{YL}_{1}$ poetic rhythm. These usages add Yoruba local colour, flavour and density to the text.

Our next examples are $O$ we usages which combine features two and four:

7. Meander how it will, the river

Ends in lakes, in seas, in the Ocean's

Savage waves. Our flood's alluvial paths

Will spring the shrunken seeds;

Rains

Shall cleanse the leaves of blood. (p. 1)

8. ... When tap roots join across the years

Twining the landness spread too vast ...

... the mind may yield

Beneath the weight of earth about to be undone
At this upheaval of our giant roots.

9. Others build and others conquer; the jackal's

Laughter turns him leader by default.

When the gaurd is empty, the tapster staggers

Homeward, drunk with self-acclaiming. (p. 16)

The maxim in 7 is unconditional, terse and pithy. It is the poet's expression of hope; an expected end, a solution to the black struggle against racism. The effect of the statement derives partly from the force of the simple parallel structural Owe types in the last two sentences. Eight and nine function like instances of $b i$ complex (that is conditional) parallel types. The lexical repetition of roots is a third feature exhibited in the usage. Although, only roots is repeated, the repetition makes the rather intricate expression more lucid, revealing the vivid proverbial description of the anticipated effects of the united forces of the black people across the continent. These rhetorics are employed with the African audience in mind, and are instances of the conative aspects of Soyinka's style.

Our last group of examples of Owe includes usages that combine three or all the features of the form:

10. The termite is no match

For the black soldier ant, yet termites gnawed

The housepost of our Kraals even while

We made the stranger welcome (p. 12)

11.The task must gain completion, our fount of being cleansed from termites' spittle In this alone. I seek my own completion. (p. 13)

12.Kind knows kind, but only as the wholeman Knows his pus-filled finger, In what I did Was Shaka, but Shaka was not always I. (p. 15)

13.Beware the life-usurpers masked in skins Flayed from the living forms of amaZulu Beware the jester masks with grinning teeth Of the corroded panga. I have spoken. (p. 17)

Eleven is the only example that combines the first, second and fourth features. All of 10,12 and 13 combine all four and even additional Yoruba stylistic features. This makes them the best examples of Owe translation employed by the poet in this anthology.

In addition to the positive maxims employed, there is also the use of structural parallelism, (SPCA) in 10, SPC in 12 and PC in 13. Lexical repetition is equally exploited in all. The repetition of termite in 10 with the colour contrast has the white racist import in the second usage especially as it is matched with stranger in the the company of the transferred lexical item kraals - a very terse and pithy proverbial expression of regret and multiple - edged satire on the white racist racists.

Kind, know and Shaka are repeated in 12 with the ironic import of the second usages of know and Shaka contrasting with the first; a proverbithat debunks the level of dishonesty and subsequent distrust among the black peoples. A similar lexical contrast by prepetition is also employed in 13 where beware is repeated as a 
warning for two seemingly contrasting but equally dangerous situations. The use of the panga, a choice necessitated also by the content, is deliberately a transferred element aimed at leaving the African thumb print on the Owe translated text. Within the Owe context, the last three-word sentence is a literal Yoruba translation. It is not a simple assertion declaring that the speaker has done some speaking as a mere activity but rather a literal rendition of the poet's $L_{1}$ manner of (an elder in particular) communicating with some amount of annoyance or resentment, the fact that he has exercised uptimum patience in giving advice, and warnings that have remained hitherto unheeded. He is then giving his final advice or opinion on the matter: "I am speaking my final word on this, if you like, heed my warning." This meaning of the expression then is found within its social semiotics.

\section{OFO}

This is Yoruba incantatory poetry, the basis of which is magic. Ofo is believed to work by sympathies through an impersonal dynamic vital force which is present in all things: objects, plants, human, or supra-human. An object, it is believed, can transmit some aspects of its nature to other bodies: sweet potatoes or honey for example can by its sweetness make life more abundant if its vital force is tapped a case of homopathic sympathy. The other sympathy is contagious; sympathies which are transferred through physical contact or relationship.

The belief in the magic of names is related to Ofo usages - all this have secret names and evoking such names enables the enchanter to control them and the power or vital force in them. Hence $O f_{0}$ or Oro mean word. Four distinguishing features of $O$ fo are its characteristic structure (invocation, statement of problem, assertion of truths), symbolic word-play, repetition, and the personal nature of the poetic form. Assertions could be negative or conditional but it is usually positive. The truth of some of the assertions is held to be mythologically defined. The following example of this type is given by Olatunji (1970: 224):

Ile o gba ona o gbaa nii sewe a a ragba

Ojo tomode ba ja we olo yin aye

Ojo naa nii foju bewe oloyin orun

TE There is no room at home there is no room outside is the fate of the a ragba leaf It is on the day that a child plucks the earthly Oloyin leaf

It is on that day that he will come face to face with the heavenly olo yin leaf.

The word-play in the example is on sound, while the assertion is based on incontrovertible observations of the world of nature. The second feature is the symbolic word-play on homophonous $\mathrm{YL}_{1}$ usages where the noun and verb forms are related. Repetition in $O f_{o}$ is marked by its magical significance.
Incidents of lexico-structural repetition in $O f o$ is higher than any other poetic form.

Ofo stylistics is skillfully employed in Ogun Abibiman. Consider the following examples:

14. Sigidi Baba! Bayete!

Our histories meet, the forests merge

With the savannah. Let rockhill drink with lion

At my waterholes. Oh brother spirits

Did my dying words raise echoes in your hills

When kinsmen matched broad blades

With Shaka's shoulders? (p. 11).

15. Bayete Baba! Bayete!

Reclaim my seeds. Restore my manhood.

Their cries are trumpeted in the dead abode...

... O silent one, my tap-roots

Wait your filling draught to swell

To buttress. Restore my seeds. Reclaim

The manhood of a founder - king

Rogbodiyan! Rogbodiyan!

Ogun re le e Shaka

Rogbodiyan

Ogun gbo wo Shaka

O di rogbodiyan.

16. Sigidi! And on the brink, a pause, a hope

Before the seal against retraction-infekane!

For who shall say of processes that strip

Millenial trees of grandear, ingenuities

Beamed to atomised the creative palm of man -

Whose song shall claim - that war is for desire

Or love, or ease, or craving?

A cherished courtesan at labour's end?

We shall not vie in sickness with that world

Whose rhetoric is sightless violence

But press the purity of claims that dwell

inward in our being... (p. 19)

These three examples of $O f o$ poetry maintain a near exact $O f o$ structure. the invocation in all instances is of the ancestral essence called forth in the African language. A number of other usages help to establish a strong sense of the African region: the flora and fauna as well as their aspirations. The meaning of the transferred, African lexical items Sigidi and Mfekane (16) intensify each other since the former is a dreaded ritual emissary of destruction who will inevitably fight in the crushing and total war (mfekane).

Still on the Ofo structure, the problem element is overtly defined in all three examples following the usual question type. The assertion in 15 and 16 produce their effects differently. In 16 it is negative and asserted in modern British English with no traits to show that the usage is from the African region, yet the preceeding part of the text as well as the context enable it to produce effectively the psychological effect often associated with $O f o$ assertions. Example 15 is the most colourful. The assertion which is rendered in $\mathrm{YL}_{1}$ is an instance of spontaneous code 
switching as the poet makes his outburst in the performance form of his native culture. The songs, the dance and the near audible African drums all combine to compensate for the poet's non-use of the most appropriate medium; $\left(\mathrm{YL}_{1}\right)$ for this special discourse about the black peoples.

\section{ALO APAMO}

This is $\mathrm{YL}_{1}$ poetry as riddles. It mainly serves an entertainment function. Five distinguishing features are: the question and answer pattern, recondite metaphour, incongruity of statements, sentence form and the sparing use of connectives. Although the riddles are interrogative, they are usually not propounded in that form; only a few are. An example of this poetic form is 17 :

17. The boughs are broken, an earthquake

Rides upon the sway of chants...

18. Ogun is the tale that wags the dog

All dogs, and all have had their day. (p. 6)

This verse form is not as overtly employed in this volume as in others. Our examples are absurd usages which derive their full meaning within the cultural context of Alo Apamo.

The total outcome of all four stylistic strategies employed in the translation of Soyinka's message in this text is a creative rendition of a melodious Yoruba verse in English - a rendition in which his African and $\mathrm{YL}_{1}$ reader can hear the African voice distinctly behind the terse, adulatory and pungent message. The poet's translation principle is more of a heuristic device because it is based not really on translation equivalence but on synonymy; a meaning relationship that is highly context (including cultural context) sensitive.

MaBel OSAKWE Delta State University, Abraka, Nigeria

\section{REFERENCES}

BANJO, L. A. (1969): A Contrastive Analysis of Yoruba and English Grammar, Ph.D. Thesis, University of Ibadan, Ibadan.

BANJO, L. A. (1970): "On Competence and Performance in Second Language", Ibadan Studies in English, 2 (1).

CATFORD, J. C. (1964): A Linguistic Theory of Translation: An Essay in Applied Linguistics, Oxford, Oxford University Press.

HALLIDAY, M. A. K. (1978) : Language and Social Semiotics: The Social Interpretation of Language and Meaning, London, Edward Arnold.

LADO, R. (1957): Linguistics Across Cultures, Michigan University Press.

OLATUNJI, O. (1970): Characteristic Features of Yoruba Oral Poetry, Ph.D. Thesis, University of Ibadan, Ibadan.

OSAKWE, M. (1992): The Language of Wole Soyinka's Poetry: A Diatype of English, Ph.D. Thesis, University of Ibadan, Ibadan.

OSUNDARE, N. (1979): Bilingual and Bicultural Aspects of Nigerian Prose Fiction, Ph.D. Thesis, York University, Toronto (Ontario).

SOYINKA, W. (1976) : Ogun Abibiman, London, Collins. 